\title{
Recovery and reuse of structural products from end-of-life buildings
}

Peter Hopkinson PhD

Professor in Circular Economy, Exeter Business School, University of Exeter, Exeter, UK (corresponding author: p.hopkinson@exeter.ac.uk)

Han-Mei Chen BEng, MSc, PhD

Research Associate, School of Mechanical, Aerospace and Civil Engineering, University of Manchester, Manchester, UK

Kan Zhou BEng, BEc, PhD

Research Associate, School of Engineering, University of Bradford, Bradford, UK
Yong Wang BA, PhD, CEng, FIStructE

Professor in Structural Engineering, School of Mechanical, Aerospace and Civil Engineering, University of Manchester, Manchester, UK

Dennis Lam BEng, MPhil, PhD, CEng, FIStructE, MICE, MASCE, MIMgt Professor in Structural Engineering, School of Engineering, University of Bradford, Bradford, UK

Buildings and construction have been identified as having the greatest potential for circular economy value creation. One source of value creation is to recover and reuse building products from end-of-service-life buildings, rather than destructive demolition and downcycling. While there is a trade in non-structural and heritage product recovery and reuse, the largest volume, mass and value of most buildings comprise structural elements - concrete, brick and masonry, and steel - which present many challenges. A comprehensive literature review confirms limited attention to innovation and advanced techniques to address these challenges and therefore the potential reuse of the stocks of accumulated building products globally and associated environmental benefits. Potential techniques being tested in an Engineering and Physical Sciences Research Council circular economy research programme are referenced as a key building block towards circular economy building system redesign.

\section{Introduction}

In a circular economy, growth comes from 'within', by increasing the value derived from existing economic structures, products and materials (EMF, 2015a) and innovation. Increased value in a circular economy, it is argued, is derived from maintaining the integrity of a product at a higher level (technical and economic durability), using products longer (repeat use), cascading use in adjacent value chains and creating pure, high-quality feedstock (avoiding contamination and toxicity). Various reports have identified construction and buildings as having the highest potential for circular economy innovation, value retention and creation opportunities (EMF, 2015b).

To achieve this industrial take-up, circular economy business models and product flows need to be more cost-effective, deliver superior revenues or improve capital and resource productivity to beat the linear model.

In a future circular economy, all end-of-service-life (EoSL) buildings will be material and product banks and deconstructable to retain high-value materials and products and, given their bulk/ value ratio, repair and remanufacture of products from EoSL buildings would be carried out and stored locally and then blended into new builds also locally to minimise cost. All this will create value, promote innovation and attract investment.

A major, immediate, seemingly intractable challenge, however, is that there is a huge legacy of materially intensive buildings and infrastructure not designed for the recovery and reuse of products due to technical economic barriers, including the lack of market mechanisms (Adams et al., 2017). The questions then arise of (a) whether it is possible to extract more products and value from the stocks of such buildings at the end of their service lives and (b) whether the products can be remanufactured and reused in future buildings. If this is possible, then the final question is (c) how to translate the potential of mining such buildings to create a new circular building construction system that coordinates and integrates key players and activities, including building and product design, dismantling and separation, high-value remanufacture and marketplace exchange. The questions form the first part of a new Engineering and Physical Sciences Research Council (EPSRC) project, Regenerative Buildings and Products for a Circular Economy (Rebuild) (EPSRC EP/P008917/1), which is investigating novel techniques for the recovery of the most common building products from load-bearing structures: structural concrete components from reinforced-concrete (RC) structures, steel from steel-concrete composite structures and bricks from masonry walls bonded by cement-based mortar. A fuller description of the project and some early findings are presented towards the end of the paper.

This paper reviews the state of the art on the topic and is structured as follows: section 3 highlights the resource intensity of building and construction materials demand within the economy. Section 4 summarises the current state of the art and evidence on the feasibility of recovery and direct reuse of building structural products within new builds, key barriers and potential environmental benefits.

\section{Literature review method}

A review of the academic literature was conducted with the Web of Science online database by using search terms including 'circular economy', 'steel', 'bricks', 'masonry', 'concrete', 'reuse', 'remanufacture' and 'recycling' for articles between 2010 and 2017. These articles were examined for how the three core 
structural materials and their accompanying terms were presented in terms of their specific research context. The papers were then systematically grouped by frequency and key terms. The review produced 241 articles on aspects of brick recycling, 26 on direct brick recovery (mainly heritage bricks) and reuse, six related specifically to steel recycling from buildings, 13 on steel recovery and reuse, 188 articles on aspects of concrete recycling and nine on direct concrete recovery and reuse.

\section{Building and material stocks and flows}

Buildings and construction are major sources of economic activity, employment and material throughput globally. The sector is also very wasteful, with estimates in the UK, for example, of between 7 and $15 \%$ of products not being used in the final construction, much of it landfilled (Adams, 2013).

Over the past century, the overall use of construction materials has increased by a factor of 42 ; the same period has seen a 23 -fold increase in the accumulation of materials $(792 \mathrm{Gt})$ within stocks of buildings and infrastructure (Krausmann et al., 2009, 2017; Wiedenhofer et al., 2015). In China, for example, stocks increased by a factor of 5 between 1978 and 2005, accounting for 55\% of global production of cement in 2010, and will likely double in the next 30 years (Herczeg et al., 2014). In-use stocks of non-metallic minerals are also high - for example, $294 \mathrm{t}$ per capita population in Japan and $337 \mathrm{t} /$ capita population in the USA. In Japan, $43 \%$ of in-use stocks are contained within buildings (Hashimoto et al., 2009). Studies at the European scale show that non-metallic minerals in European Union 25 building stocks are $72 \mathrm{t} /$ capita population, while inflows and outflows of construction materials remain significant (e.g. $2.6 \mathrm{t} /$ capita population in Paris and $6.5 \mathrm{t} /$ capita population in Vienna) and stock accumulation remains high $(1 \cdot 1 \mathrm{t} /$ capita population in Paris and $5 \cdot 5 \mathrm{t}$ /capita population in Vienna).

Globally, around $65 \%$ of total aggregates (sand, gravel and crushed rock) and approximately $20 \%$ of total metals are used by the construction sector to create the built environment. Within construction, concrete, aggregate materials (sand, gravel and crushed stone) and bricks make up $90 \%$ (by weight) of all materials used. Around $25 \%$ of all steel, $75 \%$ of all concrete, $65 \%$ of all aggregates and $70 \%$ of all bricks are used for buildings (Herczeg et al., 2014). In Europe, between 30 and 50\% (different sources give different numbers) of total material use goes to housing and mainly consists of iron, aluminium, copper, clay, sand, gravel, limestone, wood and building stone (Herczeg et al., 2014).

Construction materials in many parts of the world are also increasingly scarce. For example, the world demand for sand is outstripping supply, leading to 'peak sand' and concerns about the damage to river and ocean ecosystems in Africa and elsewhere from illegal or poorly managed sand dredging to supply global markets (UNEP, 2014).

The UK is largely self-sufficient in certain building materials, such as sand, which may contribute to the lack of incentives to address resource scarcity and promote reclaim and reuse models. Reclaim and reuse could contribute to the UK demand of around $400 \mathrm{Mt}$ of new materials each year for new, replacement or maintenance of infrastructure and buildings. Approximately 50000 buildings are demolished each year, generating $45 \mathrm{Mt}$ of construction and demolition (C\&D) wastes; the majority of this are concrete, masonry, bricks and steel (Adams, 2013). However, market conditions, low productivity and lack of capabilities and skills contribute to the downcycling of materials and destruction of potential value at EoSL.

Three recent studies, one in Melbourne (Stephan and Athanassiadis, 2018), one in Rhine-Main (Schebek et al., 2017) and one in the Rhine-Ruhr region (Oezdemir et al., 2017), offer detailed analyses of buildings at city and regional scales. In the case of Melbourne, across 14385 buildings, concrete dominates the mass of material stock (92\%) and also C\&D waste (78\%). In the Rhine-Main region, a detailed study of 19 typical examples of 6000 non-residential buildings showed concrete and bricks combined account for approximately $73 \%$ of material composition. The Rhine-Ruhr study comprised 179 residential buildings with a building gross area of $25985 \mathrm{~m}^{2}$ and total material stock of $2315 \mathrm{t} /$ capita consisting of $48 \cdot 5 \%$ concrete, $22 \cdot 2 \%$ bricks and $3 \cdot 5 \%$ metal. A further material analysis calculated sand and gravel contributed $70 \cdot 3 \%$, marl and clay $14 \cdot 75 \%$ and cement approximately $9 \cdot 3 \%$ of the mass.

The figures confirm buildings as a major stock of materials, which continues to accumulate. These materials will be released through time as buildings come to their EoSLs. However, recycling of construction materials will downgrade performance (Augiseau and Barles, 2017). The challenge then is to find different ways to meet the future demands for construction products by reusing existing products to reduce pressure on supplies and externalities. Some high-level principles, key building blocks and spatial configurations for system-level redesign for buildings and construction have been set out in Growth Within (EMF, 2015a) and a study of Amsterdam City (Circle Economy, 2016). A better approach higher up the value chain is to reclaim and remanufacture products and redesign the construction system to achieve superior economic, material and social value against a base linear case.

\section{Recovery and reuse of building products}

The potential benefits of recovering and reusing building structural products are an attractive proposition, for a variety of reasons. Building products are a high percentage of construction cost and have high embodied energy (EE) (Bribian et al., 2011). Steel and aluminium together are responsible for approximately $51 \%$ of the total $\mathrm{EE}$ in building materials, with concrete responsible for another approximately 17\% (Diener and Tillman, 2015). While the direct maintenance and reuse of products have significant environmental benefits over recycling, only a small percentage in the UK (approximately $3 \mathrm{Mt}$ ) are reclaimed for direct reuse, mostly for heritage products or easily demountable 
structures such as steel sections from portal frames (around $4 \%$ of all steel in buildings is reused against $92 \%$ recycled). In the case of brick, concrete and other masonry, the figures for direct reuse are even lower.

If a building product could be recovered directly and reused costeffectively, rather than recycled, it could offer both cost and multiple resource and environmental benefits. As an example, steel reuse in the UK is profitable at recovery cost below $£ 200-400 / t$ (Newman, 2016). The challenge, however, is that the majority of existing buildings were not designed for adaptation, disassembly or high-value reuse. While renovation and refurbishment are usually preferable from an overall materials or energy perspective (Crawford et al., 2014), there is a huge legacy of buildings where this may be technically difficult or not costeffective. Where a building is judged to be at the end of its useful or service life, demolition is often considered a cost to be minimised, with the speed of site clearance commercially critical. Moreover, despite having many innovative companies and products, the building and construction sector lacks confidence in the performance of reused product, such as steel (Dunant et al., 2017) - and there is also the cost of recertification - leading to limited demand and a business-as-usual approach. Given that the majority of structural materials would be under working (elastic) load during their working life, they are fully capable of meeting engineering requirements and being reused as new. Industry codes of practice or standards do not prohibit the use of reclaimed products, but without such a specific code or industry standard, designers and specifiers do not know how to deal with them.

There is a growing interest and practice in methods of design for deconstruction to ensure future circularity, although much of this focuses on using new materials and products, instead of using EoSL buildings as potential feedstock. In combination, these and other factors mean that the building and construction sector will continue to opt for demolition and recycling EoSL wastes (usually to create aggregate for on-site backfill) unless new techniques and approaches to demolition and recovery become technically feasible and, most importantly, commercially viable.

The rest of this section summarises some of the key challenges that need to be overcome for steel, concrete, brick and masonry recovery and the potential for new or novel techniques and system enablers that could create reuse of higher value.

\subsection{Steel}

The issue of steel reuse and recycling has been increasingly addressed by researchers worldwide, particularly in the steel industry (Broadbent, 2016; Wang et al., 2017) and manufacturing industry (Diener and Tillman, 2015; Dunant et al., 2017). However, while the combined rate of reuse and recycling of steel in the UK increased from 93 to $96 \%$ over the period from 2000 to 2012 (Sansom and Avery, 2014), this is dominated by recycling, with reuse being less than $4 \%$. Although structural steel elements are inherently reusable with minimal reprocessing, reclaiming structural steel elements from existing buildings poses significant technical challenges. Structural elements where steel is used are rarely made of steel only and are usually composite steel-concrete construction. Webster and Costello (2005) suggested that composite construction is a barrier to deconstruction and recommended that it should be avoided in design for deconstruction; in this type of construction, the steel product is connected to the concrete through welded shear studs. Separating structural steel elements from concrete requires further research (Rehman et al., 2018). However, it is expected that reuse would change the way that the construction sectors operate and create new business developments (Lacovidou and Purnell, 2016).

For steel reuse to become widespread and scalable, various practical barriers have been identified: cost of recovery, availability/storage, demand, traceability and supply chain gaps/ lack of integration (Tingley et al., 2017). Dunant et al. (2017) highlighted similar issues and the importance of collaboration between contractors, stockists and fabricators to facilitate steel reuse economically. They also pointed out that a market for reusing steel can exist on the condition that selling reused steel is more profitable to stockists than selling scrap. Dunant et al. (2018) highlighted that the supply chain should include specialised stockists to make the market for steel reuse more favourable. Techniques such as semi-automatic geometric characterisation have also been proposed as key requirements to increase steel reuse (Yeung et al., 2015). Smarter technologies and alternative business models have also been recognised as key to support the practice of steel reuse (Ness et al., 2015). A core challenge in steel building product reuse is the testing and verification of material properties. Research in this field is limited. Fujita and Masuda (2014) proposed a non-destructive evaluation procedure for determining the steel grade to reuse steel structural members. Through a case study, it was shown that accurate tensile strength and chemical compositions could be derived from non-destructive tests. These values were evaluated against the Japanese codes and were found to be consistent with the design specification.

\subsection{Brick}

It is estimated that around 2.5 billion bricks in the UK (Kay and Essex, 2008) are demolished annually, although $<5 \%$ of these are reclaimed for reuse. Many of these bricks are crushed long before the end of their technical life, losing their EE and other natural resources (Thormark, 2000). Approximately 50\% are under hybrid recycling - that is, crushed along with other masonry materials and used in hardcore and fill.

Brick construction is typically made of bricks bonded by mortar. The two mortar types are lime-based mortar and ordinary Portland cement (OPC)-based mortar. Lime-based mortar is commonly used in historical masonry buildings. It also degrades over time. Therefore, after a long period of time in use, lime-based mortar will have little residual bond strength and it is relatively easy to separate bricks with lime-based mortar. The majority of research 
papers on brick reuse address the dating, recovery and reuse of heritage bricks from lime-based mortar (BDA, 2014; Bouvier et al., 2013; Cristini et al., 2014; Gorgolewski, 2008; Pesce et al., 2013; Quagliarini et al., 2014; Serlorenzi et al., 2016). Sisti et al. (2016) have introduced a retrofitting technique for masonry buildings by a ring beam made of reused bricks. Thormark (2000) reported that about $85 \%$ of the bricks with lime-based mortar can be perfectly separated. The rest can be assumed to be damaged and therefore suitable only for material recycling as a substitute for natural gravel. The Institution of Civil Engineers' Demolition Protocol (ICE, 2008) states that bricks have a recovery potential of $10 \%$ - rising to $100 \%$ in some buildings. The Brick Development Association (BDA, 2014: pp. 10-11) concluded that 'the use of reclaimed bricks should not be discouraged provided that users are conscious of their qualities and the associated property testing of re-used bricks is required... Their high cost is a reflection of demand and the cost of reclamation...'. Currently, the removal techniques of lime-based mortar are mostly manual, using a heavy/brick hammer and broad cold chisel or bolster (BDA, 2014), demolition hammer or brick cleaner machines (KHR Company Ltd, 2017). Although these methods are very time-consuming, they are at least technically feasible, even though it is not practical for them to reclaim on a brick-by-brick basis (Yeap et al., 2012). Recent projects such as Rebrick (2013) have shown the potential for recovery of bricks from lime mortar by an automatic brick-cleaning system.

The preceding methods will be neither possible nor ideal to reclaim bricks with OPC-based mortar commonly used in contemporary masonry buildings because the mortar retains very high bond strength and is much harder to remove (Hobbs and Hurley, 2001).

\subsection{Concrete}

As previously described, concrete forms the largest proportion of building stocks. The current dominant end-of-life scenario for concrete buildings and their elements is demolition well before the material technical end of life (Asam, 2007). Concrete structural elements are difficult to reclaim (Durmisevic, 2010); hence, there has been a greater focus on recycling rather than reuse. In some cases, the demolished concrete passes through a recycling process in which it is crushed to separate reinforcing steel; the resulting crushed material is used, for example, for road beds. Methods and techniques for increasing the quality, durability and tension-stiffening properties of recycled concrete are widely researched (Kisku et al., 2017; Rangel et al., 2017; Xiao et al., 2016). The applications of recycled concrete blocks, characterised by a size larger than that of conventional recycled aggregates, in composite structures have also been investigated (Chen et al., 2016). Reusing larger-sized recycled concrete blocks is a half-way house between the conventional use of recycled aggregates and the ideal situation of using complete recovered concrete products. Given the current situation of relatively mature methods of recovering materials and challenges of reclaiming complete structural products, this may represent an immediately achievable practice of obtaining higher-value use of recycled concrete.

To shift from recycling to reclaim and direct reuse requires new techniques; there are two generic types of RC structures: in situ construction and precast construction. In in situ construction, the concrete of the building is cast together to form a monolithic mass. The only means of separating structural elements in such construction would be to cut through the structure. A further issue with reclaiming RC structural elements is their reuse. Due to the flexibility of changing dimensions and the amount of reinforcement, RC structural elements do not have standard dimensions and standard reinforcement amount and layout. This makes it difficult to join reclaimed RC structural elements.

In contrast, it is possible to reclaim RC structural elements from prefabricated concrete structures because the prefabricated elements were assembled together in the first cycle of construction. Huuhka et al. (2015) have reviewed the reuse potential of over 26000 prefabricated concrete wall panels and nearly 14000 hollow-core slabs in Finnish 1970s mass housing, along with the review of technical prerequisites for reuse. The panels are found to be still usable in architectural (plan) design of detached houses, which form one-third of annual residential production in Finland. In addition to having a very low carbon dioxide $\left(\mathrm{CO}_{2}\right)$ footprint, reuse of concrete panels reduced the cost of new construction by $20-30 \%$ (Huuhka, 2010a, 2010b; Huuhka et al., 2015). Yeap et al. (2012), however, highlight the costs of handling and storing concrete building components, which could make recovery and reuse uneconomic. To overcome this would require matching the supply of reclaimed product with the demand at the local or regional level. One example of how this might be achieved is currently taking place in Kerkrade, Netherlands. This innovation project is aimed at reusing and recycling $100 \%$ of materials acquired from the demolition of an outdated 100-person social housing high-rise block of flats to create four new units co-designed with residents (UIA, 2018).

In summary, the review of the literature reveals that much less attention has been given to structural product recovery and reuse compared to recycling. The available reuse literature has often considered structural elements to present intractable challenges and, hence, little promotion of technical innovation and novel techniques. Early results from Rebuild are promising in showing the potential to reclaim structural elements. The shift from recycling to reuse, however, is not just simply a technical challenge but requires analysis of whether the effort is justifiable in terms of environmental savings.

\section{Environmental impacts}

The reduction, reuse, recovery and recycling of EE/embodied carbon dioxide (EC)-intensive construction materials/products were one of the main EC mitigation strategies proposed by Pomponi and Moncaster (2016). However, research on the comparative environmental performance of reused structural 
Table 1. A comparative EE analysis of virgin steel, brick and concrete

\begin{tabular}{|c|c|c|c|c|}
\hline \multirow{2}{*}{ Selected source } & \multicolumn{3}{|c|}{$\mathrm{EE}: \mathrm{MJ} / \mathrm{kg}$} & \multirow{2}{*}{ Region } \\
\hline & Steel & Brick & Concrete & \\
\hline Milne and Reardon (2013) & 38 (galvanised) & $2 \cdot 5$ & $1 \cdot 5-2 \cdot 0$ & Australia \\
\hline Tectonica-online (2018) & 35 (20\% recycled) & $2 \cdot 9-3 \cdot 0$ & $1 \cdot 0-1 \cdot 1$ & - \\
\hline Hammond and Jones (2011) & $35 \cdot 4$ & $3 \cdot 0$ & $0 \cdot 7-1$ & UK \\
\hline Morton (2006) & - & $\begin{array}{c}3.8 \\
0.5 \\
\text { (unfired) }\end{array}$ & - & UK \\
\hline Berge (2009) & 25 (galvanised) & 3 & $1 \cdot 5$ & Norway \\
\hline Alcorn (2003) & $31 \cdot 3$ & $\begin{array}{c}2 \cdot 7 \\
0 \cdot 1 \\
\text { (unfired) }\end{array}$ & $0 \cdot 9-1 \cdot 4$ & New Zealand \\
\hline All database sources & $25-38$ & $0 \cdot 1-3 \cdot 0$ & $0 \cdot 7-2 \cdot 0$ & \\
\hline
\end{tabular}

building materials against recycled and virgin products is fragmented and sparse. In contrast, there is a strong research literature comparing recycled against new products with mixed conclusions, depending on the nature of the product. It is not always the case, for example, that recycling has a better overall energy and carbon dioxide performance than using virgin materials, such as the case with recycled concrete (Huuhka et al., 2015), although much effort is spent exploring new techniques to improve processes. Other studies, however, have shown the lifecycle impacts of recycled concrete to be lower compared to those of conventional concrete (Knoeri et al., 2013).

Virgin steel, brick and concrete are energy- and carbon dioxideintensive products which have used a great deal of energy during manufacture (Berge, 2009). Table 1 illustrates the range in EE in megajoules per kilogram from selected studies on these products,

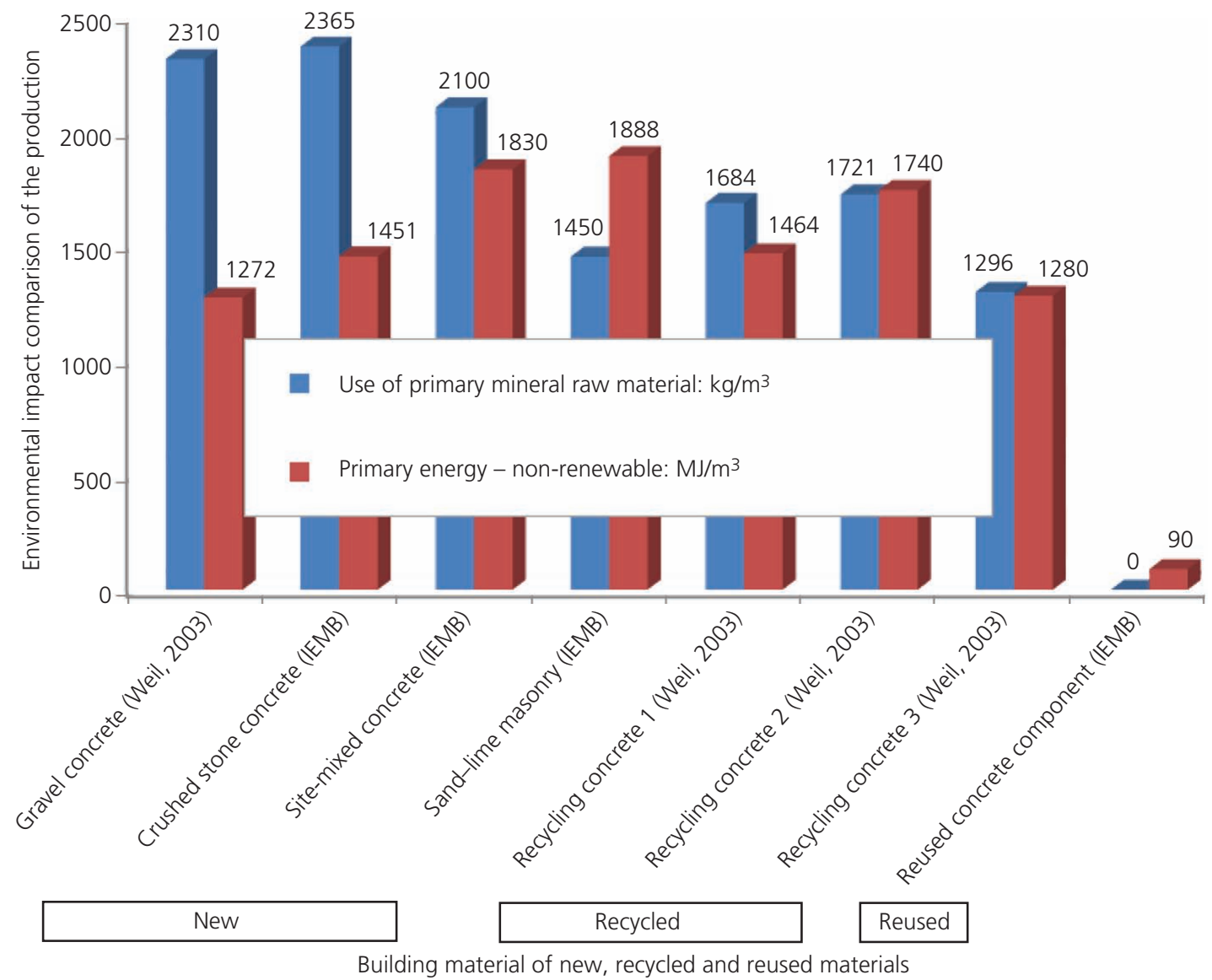

Figure 1. Environmental impact comparison of the production (up to the factory gate) of a cubic metre of building material of new, recycled and reused materials (Glias, 2013). IEMB, Institut für Erhaltung und Modernisierung von Bauwerken e. V. 
which vary significantly around the overall average. The percentage contribution of total EC and EE attributable to each life-cycle stage of the products and the building can be identified by a newly designed tool (Moncaster and Symons, 2013).

The number of studies comparing steel reuse to recycling is limited. A case study of reuse of steel structures without melting demonstrated that this reuse of steel could allow for 30\% savings in energy and carbon dioxide reduction (Pongiglione and Calderini, 2014). A complete $3250 \mathrm{~m}^{2}$ steel frame warehouse relocation in the UK demonstrated both the technical feasibility of deconstruction and reassembly and an overall $38 \%$ carbon dioxide reduction compared to a benchmark building (Segro, 2013), a figure similar to that from an earlier steel reuse study (Gorgolewski et al., 2006). Studies on reuse of bricks are equally limited. The Rebrick (2013) study estimated that each reused brick will save $0.5 \mathrm{~kg}$ of carbon dioxide emissions compared to building with new bricks. A US study estimated that the percentage of source reduction of bricks that occurs when reusing bricks can be 0.0788 metric $t$ carbon dioxide equivalent per tonne (US EPA, 2003).

Environmental life-cycle assessment (LCA) of concrete is more widespread. Concrete has relatively high EE due to the use of clinker in its composition, which creates $1 \mathrm{t}$ of carbon dioxide per tonne of clinker (Cabeza et al., 2013). A study comparing new against reused precast double-T concrete reported $1.23 \mathrm{GJ}$ of energy savings, $147 \mathrm{~kg}$ reduction in carbon dioxide production and $50 \%$ reduction in water and air emissions per cubic metre of product (Catalli, 2009). Glias (2013) compared reused concrete components to recycling or virgin sources (Figure 1).

In Figure 1, recycling concrete 1, 2 and 3 refer to three types of mix for recycled concrete; gravel concrete, crushed stone and sitemixed concrete refer to three types of new concrete; and reused concrete component refers to reused concrete prefabricated part. When comparing recycling concrete 3 with new concrete, a 50\% reduction in primary raw materials is observed for the recycled concrete, but on the other hand, there is no improvement on the energy values. Reuse is between 92 and $97 \%$ lower than recycling in primary energy and global warming potential (Glias, 2013).

\subsection{Rebuild}

The Rebuild project is designed to translate the potential of building product reuse to reality (Figure 2). Funded by EPSRC, this project seeks to connect two ends of the building and construction value chain to overcome many of the barriers previously cited. Achieving this requires a new circular building construction system that coordinates and integrates key players and activities, including building and product design, dismantling and separation, high-value remanufacture and marketplace exchange at the regional scale to capture the potentials for circular economy innovation, value retention and creation opportunities (see Figure 2). Rebuild focuses on the major challenge of legacy buildings and the potential to create value from remanufacturing products of buildings at EoSL

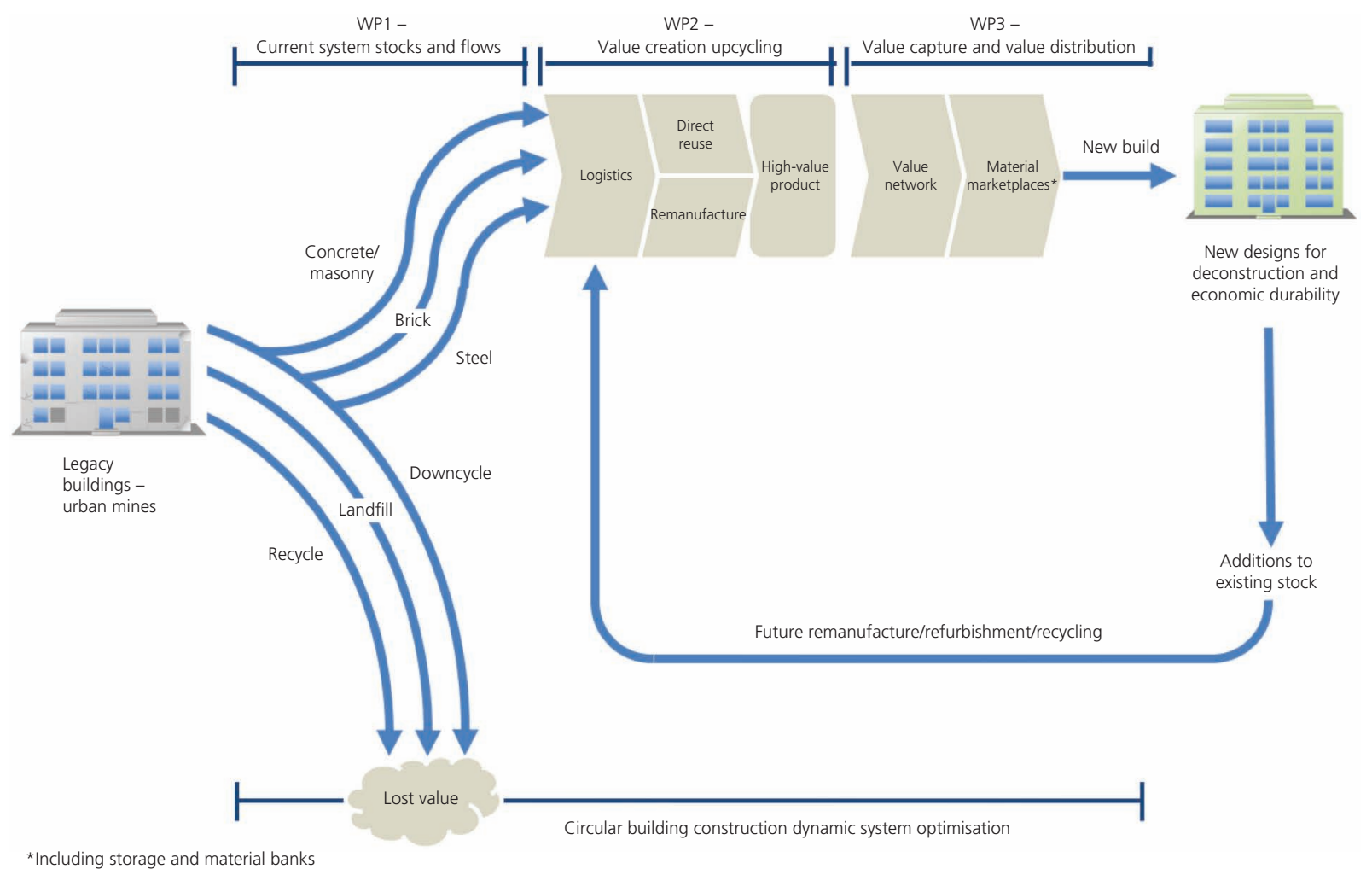

Figure 2. Visual overview of the Rebuild project 
into high-value durable products with minimal reprocessing for new builds, which themselves should be designed for future deconstruction and product reuse, and the system innovations required at the regional scale. The focus of the project is three northern UK cities, Manchester, Leeds and Bradford.

The objectives of the project are (a) systematic understanding and modelling of the quantities of building product within current and future EoSL building stocks and barriers to reuse (WP1); (b) new demolition, separation, repair and remanufacture techniques (e.g. three-dimensional printing) that lead to the maximum amount of reusable components at the highest value (WP2); (c) quantifying the reuse potential, material and environmental impact, costavoidance and value-creation potential for each category of reusable product against new product for different categories of new build (WP2 and WP3); and (d) defining and optimising circular system elements (building design techniques, product choices, fabrication centres, upcycling facilities, logistics, resource bank storage, marketplaces, future construction locations, locations of product repair and remanufacture techniques), configurations and arrangements that will create opportunities for value creation and capture and how these affect decisions about the pathways of reusable product and their impacts (WP3).

The project is at an early stage. Table 2 summarises some of the key year 1 activities and early findings to assess the potential stocks of reclaimable products and address the technical challenges for reclaim and reuse of steel, concrete and brick. The analysis and innovation of economic, legal, environmental and wider system requirements to make the shift to a circular economy system will build on these stages.

\section{Conclusions}

Construction minerals account for the highest extraction rate of raw materials worldwide, and buildings present the largest material stock. To create a circular economy building system requires an ability to couple closely the recovery and reuse of products from end-of-life buildings to stock replacement and maintenance. The majority of research on the reuse of structural materials from end-of-life buildings has focused on methods to improve quantification of recycling rates and quality, rather than product recovery and direct reuse. As a result, little attention has been given to the LCA environment benefits of reuse rather than recycled or new product (Tingley and Davison, 2012). Where studies have been conducted, the evidence demonstrates the significant energy, carbon dioxide and resource benefits of reuse.

In a circular economy, building and construction system demand will be created through a combination of factors, including efficient and proven techniques for selective deconstruction and segregation of products, cost-effective remanufacturing and reuse certification processes, that creates competitively priced products and breeds confidence, coupled with building designs that are better equipped to incorporate reused products and shifts in procurement policies and regulation to stimulate reused product. Individual innovations such as online marketplaces and exchanges for building wastes and products (e.g. Enviromate, Recipro and Construction Material Exchange), product tracking and monitoring such as material passports, amended LCA tools (e.g. BS EN 15804:2012 (BSI, 2012)) and building information modelling for manufacturing and manufacturers have a contributory role in accelerating an effective end-to-end product reuse system.

Table 2. Summary of key activities from the Rebuild project

\begin{tabular}{|c|c|}
\hline Challenge & Activity and potential solution \\
\hline $\begin{array}{l}\text { Evaluating total stocks and flows of structural construction } \\
\text { materials }\end{array}$ & $\begin{array}{l}\text { Local authority data sets, land-use statistics, Google Earth, four-dimensional } \\
\text { visualisation modelling and building typologies are being used to estimate total } \\
\text { stocks of brick, steel, concrete at regional-scale and small-scale sample sites for } \\
\text { most common building types/ages. }\end{array}$ \\
\hline Overcoming the challenges of steel reclaim and reuse & $\begin{array}{l}\text { Laser is used to cut welded shear studs to separate steel and concrete in } \\
\text { composite construction. }\end{array}$ \\
\hline Reuse of RC elements & $\begin{array}{l}\text { Technical feasibility of joining reclaimed RC elements - for example, by cutting } \\
\text { slots in reclaimed RC elements to accommodate reinforcement link bars. }\end{array}$ \\
\hline Repair of concrete elements & Three-dimensional printing. \\
\hline $\begin{array}{l}\text { Overcoming the challenges of brick/concrete masonry } \\
\text { recovery }\end{array}$ & $\begin{array}{l}\text { Laboratory-scale development of punching and saw cutting to reclaim cement- } \\
\text { bonded bricks has demonstrated the technical feasibility of these approaches. } \\
\text { The next step is to prove their commercial viability by improved design and } \\
\text { machinery implementation. }\end{array}$ \\
\hline $\begin{array}{l}\text { Creating new products to facilitate deconstruction of future } \\
\text { composite steel-and-concrete construction }\end{array}$ & $\begin{array}{l}\text { A new form of demountable shear stud to replace the traditional welded stud is } \\
\text { being investigated and tested. }\end{array}$ \\
\hline $\begin{array}{l}\text { Creating higher-value products to improve the economics } \\
\text { of reclaim }\end{array}$ & $\begin{array}{l}\text { Technical options for remanufacturing the brick into higher-value products such } \\
\text { as brick slips as facades for modern construction systems. }\end{array}$ \\
\hline $\begin{array}{l}\text { Comparative environmental assessment of virgin against } \\
\text { recycled against reused products at regional scale }\end{array}$ & $\begin{array}{l}\text { Initial work on product-against-product life-cycle assessment (LCA) comparison is } \\
\text { underway. Novel regional-scale LCA and circularity metrics are being developed } \\
\text { to enable regional whole-system comparisons. }\end{array}$ \\
\hline New codes and industry standards to build confidence & $\begin{array}{l}\text { The mechanical and durability properties of reclaimed materials will be compared } \\
\text { to those of new ones, and draft design codes and standards will be produced. }\end{array}$ \\
\hline
\end{tabular}


The focus of this paper is concrete, brick, masonry and steel, which represent the largest mass of structural products in the majority of buildings globally and by far the largest percentage of C\&D waste, much of it downcycled at the end of building service life. For high-volume and high-value structural product reuse to become mainstream in the UK building construction industry, it is imperative that the barriers to deconstructing EoSL buildings, including masonry with cement-based mortar, RC and steel-concrete composite structures, which account for the vast majority of UK building construction tonnage and cost, must be overcome.

For RC structures, reusing larger recovered concrete blocks may solve the problem of labour intensity and downgraded performance associated with recycling and overcome the technical challenges associated with recovering and reusing complete structural products.

Further converting the current linear life-cycle model of structural elements to a circular one requires new ways of designing structures and buildings to support disassembly potential for reuse and adaptation, where elements such as frames, wall panels, roof slabs and even columns and beams can be disassembled without material loss or pollution to be reused in extending existing buildings or in the production of new ones (Salama, 2017).

\section{Acknowledgements}

The authors gratefully acknowledge the Engineering and Physical Sciences Research Council for funding this research project Rebuild (EPSRC EP/P008917/1) and would like to thank all those who contributed to this project.

\section{REFERENCES}

Adams K (2013) CD\&E WASTE: Halving Construction, Demolition and Excavation Waste to Landfill by 2012 Compared to 2008. The Green Construction Board, London, UK, Report 017. See http://www. greenconstructionboard.org/otherdocs/ CD\&E waste from landfill 2011 Report.pdf (accessed 18/07/2018).

Adams KT, Osmani M, Thorpe T and Thornback J (2017) Circular economy in construction: current awareness, challenges and enablers. Proceedings of the Institution of Civil Engineers - Waste and Resource Management 170(1): 15-24, https://doi.org/10.1680/jwarm.16.00011.

Alcorn A (2003) Embodied Energy and $\mathrm{CO}_{2}$ Coefficients for NZ Building Materials. Centre for Building Performance Research, Victoria University of Wellington, Wellington, New Zealand.

Asam C (2007) Recycling Prefabricated Concrete Components - a Contribution to Sustainable Construction. Institute for Preservation and Modernisation of Buildings, Technical University of Berlin, Berlin, Germany, IEMB Info 3/2007.

Augiseau V and Barles S (2017) Studying construction materials flows and stock: a review. Resources, Conservation and Recycling 123: 153-164, https://doi.org/10.1016/j.resconrec.2016.09.002.

BDA (Brick Development Association) (2014) BDA Comment on the Use of Reclaimed Clay Bricks. BDA, London, UK, pp. 10-11. See http:// www.brick.org.uk/admin/resources/g-reclaimed-brickwork.pdf (accessed 05/11/2017)

Berge B (2009) The Ecology of Building Materials. Architectural Press, Oxford, UK.
Bouvier A, Guibert P, Blain S and Reynaud JF (2013) Interdisciplinary study of the early building phases of St Irenee's Church (Lyon, France): the contribution of luminescence dating. Archeosciences Revue D Archeometrie 37: 155-173, https://doi.org/10.4000/ archeosciences.4053.

Bribian IZ, Capilla AV and Usón AA (2011) Life cycle assessment of building materials: comparative analysis of energy and environmental impacts and evaluation of the eco-efficiency improvement potential. Building and Environment 46(5): 1133-1140, https://doi.org/10.1016/j. buildenv.2010.12.002.

Broadbent C (2016) Steel's recyclability: demonstrating the benefits of recycling steel to achieve a circular economy. International Journal of Life Cycle Assessment 21(11): 1658-1665, https://doi.org/10.1007/ s11367-016-1081-1.

BSI (2012) BS EN 15804:2012+A1:2013: Sustainability of construction works. Environmental product declarations. Core rules for the product category of construction products. BSI, London, UK.

Cabeza LF, Barreneche C, Miró L et al. (2013) Low carbon and low embodied energy materials in buildings: a review. Renewable and Sustainable Energy Reviews 23: 536-542, https://doi.org/10.1016/j. rser.2013.03.017.

Catalli V (2009) Design for disassembly - early planning means an economic afterlife for buildings. Sustainable Architecture and Building Magazine, 27 October, pp. 41-46. See http://www.sabmagazine.com/ blog/2009/10/27/design-for-disassembly/ (accessed 10/01/2018).

Chen Z, Xu J, Chen Y and Lui EM (2016) Recycling and re-use of construction and demolition waste in concrete-filled steel tubes: a review. Construction and Building Materials 126: 641-660, https:// doi.org/10.1016/j.conbuildmat.2016.09.063.

Circle Economy (2016) Circular Amsterdam: a Vision and Action Agenda for a Circular Amsterdam. Circle Economy, Amsterdam, the Netherlands. See http://www.circle-economy.com/wp-content/uploads/2016/04/CircularAmsterdam-EN-small-210316.pdf (accessed 18/07/2018).

Crawford K, Johnson C, Davies F, Joo S and Bell S (2014) Demolition or Refurbishment of Social Housing? A Review of the Evidence. Urban Lab and Engineering Exchange, University College London, London, UK.

Cristini V, Mileto C, Lopez-Manzanares FV and Checa JRR (2014) Recycling of Bricks in Rammed Earth Walls. CRC Press, Boca Raton, FL, USA.

Diener DL and Tillman AM (2015) Component end-of-life management: exploring opportunities and related benefits of remanufacturing and functional recycling. Resources, Conservation and Recycling 102: 80-93, https://doi.org/10.1016/j.resconrec.2015.06.006.

Dunant CF, Drewniok MP, Sansom M et al. (2017) Real and perceived barriers to steel re-use across the UK construction value chain. Resources, Conservation and Recycling 126: 118-131, https://doi.org/ 10.1016/j.resconrec.2017.07.036.

Dunant CF, Drewniok MP, Sansom M et al. (2018) Options to make steel reuse profitable: an analysis of cost and risk distribution across the UK construction value chain. Journal of Cleaner Production 183: 102-111, https://doi.org/10.1016/j.jclepro.2018.02.141.

Durmisevic E (2010) Green Design and Assembly of Buildings and Systems, Design for Disassembly: a Key to Life Cycle Design of Buildings and Building Products. VDM Verlag Dr. Müller, Saarbrucken, Germany.

EMF (Ellen MacArthur Foundation) (2015a) Growth Within: a Circular Economy Vision for a Competitive Europe. EMF, Cowes, UK. See http:/www.ellenmacarthurfoundation.org/assets/downloads/ publications/EllenMacArthurFoundation Growth-Within July15.pdf (accessed 19/07/2018)

EMF (2015b) Delivering the Circular Economy: a Tool Kit for Policymakers. Construction and Real Estate. EMF, Cowes, UK. See https://www. ellenmacarthurfoundation.org/assets/downloads/publications/Ellen MacArthurFoundation_PolicymakerToolkit.pdf (accessed 19/07/2018). 
Engineering Sustainability

Volume 172 Issue ES3
Recovery and reuse of structural products

from end-of-life buildings

Hopkinson, Chen, Zhou, Wang and Lam
Fujita M and Masuda T (2014) Application of various NDT methods for the evaluation of building steel structures for re-use. Materials 7(10) 7130-7144, https://doi.org/10.3390/ma7107130.

Glias A (2013) The 'Donor Skelet': Designing with Re-used Structural Concrete Elements. MSc thesis, Delft University of Technology, Delft, the Netherlands.

Gorgolewski M (2008) Designing with re-used building components: some challenges. Building Research \& Information 36(2): 175-188, https://doi.org/10.1080/09613210701559499.

Gorgolewski M, Straka V, Edomnds J and Sergio C (2006) Facilitating Greater Re-use and Recycling of Structural Steel in the Construction and Demolition Process. Ryerson University, Toronto, Ontario, Canada. See https://www.nrcan.gc.ca/sites/www.nrcan.gc.ca/files/ mineral smetals/pdf/mms-smm/busi-indu/rad-rad/pdf/re-ste-fin-eng.pdf (accessed 28/08/2015).

Hammond GP and Jones C (2011) Inventory of Carbon \& Energy Version 2.0 (ICE V2. 0). Department of Mechanical Engineering, University of Bath, Bath, UK.

Hashimoto S, Tanikawa H and Moriguchi Y (2009) Framework for estimating potential wastes and secondary resources accumulated within an economy - a case study of construction minerals in Japan. Waste Management 29(11): 2859-2866, https://doi.org/10.1016/j. wasman.2009.06.011.

Herczeg M, McKinnon D, Milios L et al. (2014) Resource Efficiency in the Building Sector: Final Report to DG Environment. European Commission, Brussels, Belgium. See http://ec.europa.eu/environment/ eussd/pdf/Resource $\% 20$ efficiency $\% 20$ in $\% 20$ the $\% 20$ building $\%$ 20sector.pdf (accessed 18/07/2018).

Hobbs G and Hurley J (2001) Deconstruction and the re-use of construction materials. In Deconstruction and Materials Re-use: Technology, Economic, and Policy: Proceedings of the CIB Task Group 39 - Deconstruction Meeting (Chini AR (ed.)). International Council for Research and Innovation in Building Construction, Wellington, New Zealand, pp. 98-124.

Huuhka S (2010a) Kierrätys arkkitehtuurissa: Betonielementtien ja muiden rakennusosien uudelleenkäyttö uudisrakentamisessa ja lähiöiden energiatehokkaassa korjaus- ja täydennysrakentamisessa. MSc thesis, Tampere University of Technology, Tampere, Finland. See http://URN.fi/ URN:NBN:fi:tty-201004161101 (accessed 19/07/2018) (in Finnish).

Huuhka S (2010b) Purkubetoni kierrätetään tienpohjiksi -tulevaisuudessa ehkä myös taloiksi. Betoni 2010(2): 50-55. See https://betoni.com/wpcontent/uploads/2015/09/BET1002-50-55-.pdf (accessed 10/05/2018) (in Finnish).

Huuhka S, Kaasalainen T, Hakanen JH and Lahdensivu J (2015) Reusing concrete panels from buildings for building: potential in Finnish 1970s mass housing. Resources Conservation and Recycling 101: 105-121, https://doi.org/10.1016/j.resconrec.2015.05.017.

ICE (Institution of Civil Engineers) (2008) Demolition Protocol 2008. ICE, London, UK. See https://apps2.staffordshire.gov.uk/scc/TrimDoc Provider/?ID=13/174 (accessed 09/01/2018).

Kay T and Essex J (2008) Pushing Reuse: towards a Low-carbon Construction Industry. Salvo Llp, London, UK, BioRegional, Wallington, UK. See https://bioregional.com.au/wp-content/uploads/ 2015/05/PushingReuse.pdf (accessed 20/11/2017).

KHR Company Ltd (2017) Paoloni - Brick Cleaner. KHR Company Ltd, Southampton, UK. See http://brickcleaningmachine.co.uk/ (accessed 20/10/2017).

Kisku N, Joshi H, Ansari M et al. (2017) A critical review and assessment for usage of recycled aggregate as sustainable construction material. Construction and Building Materials 131: 721-740, https://doi.org/10. 1016/j.conbuildmat.2016.11.029.

Knoeri C, Sanyé-Mengual E and Althaus HJ (2013) Comparative LCA of recycled and conventional concrete for structural applications. International Journal of Life Cycle Assessment 18(5): 909-918, http:// doi.org/10.1007/s11367-012-0544-2.
Krausmann F, Gingrich S, Eisenmenger N et al. (2009) Growth in global materials use, GDP and population during the 20th century. Ecological Economics 68(10): 2696-2705, https://doi.org/10.1016/j.ecolecon. 2009.05.007.

Krausmann F, Wiedenhofer D, Lauk C et al. (2017) Global socioeconomic material stocks rise 23-fold over the 20th century and require half of annual resource use. Proceedings of the National Academy of Sciences of the United States of America 114(8): 1880-1885, https://doi.org/10. 1073/pnas.1613773114.

Lacovidou E and Purnell P (2016) Mining the physical infrastructure: opportunities, barriers and interventions in promoting structural components re-use. Science of the Total Environment 557-558: 791-807, https://doi.org/10.1016/j.scitotenv.2016.03.098.

Milne G and Reardon C (2013) Your Home: Australia's Guide to Environmentally Sustainable Homes. Embodied Energy, 5th edn. Australian Government, Department of Industry, Canberra, Australia. See http://www.yourhome.gov.au/sites/prod.yourhome.gov.au/files/pdf/ YOURHOME-Materials-EmbodiedEnergy.pdf (accessed 12/05/2018).

Moncaster AM and Symons KE (2013) A method and tool for "cradle to grave' embodied carbon and energy impacts of UK buildings in compliance with the new TC350 standards. Energy and Buildings 66: 514-523, https://doi.org/10.1016/j.enbuild.2013.07.046.

Morton T (2006) Feat of clay. Materials World 14(1): 2-3. See http://www.arc-architects.com/downloads/Materials-World-Article-Jan2006.pdf (accessed 14/08/2018).

Ness D, Swift J, Ranasinghe DC, Xing K and Soebarto V (2015) Smart steel: new paradigms for the re-use of steel enabled by digital tracking and modelling. Journal of Cleaner Production 98: 292-303, https:// doi.org/10.1016/j.jclepro.2014.08.055.

Newman G (2016) Overcoming the barriers to steel reuse within construction. Alliance for Sustainable Building Products Resource Conference, March 2016, London, UK. See https://asbp.org.uk/wpcontent/uploads/2016/08/Gary-Newman-Resource-9th-Marchfinal.pdf (accessed 31/07/2016).

Oezdemir O, Krause K and Hafner A (2017) Creating a resource cadaster - a case study of a district in the Rhine-Ruhr Metropolitan Area. Buildings 7(2): 45, https://doi.org/10.3390/buildings7020045.

Pesce GL, Micheletto E, Quarta G et al. (2013) Radiocarbon dating of mortars from the baptismal font of the San Lorenzo Cathedral of Alba (Cuneo, Italy): comparison with thermoluminescence dating of related bricks and pipes. Radiocarbon 55(2-3): 526-533, https://doi.org/10. 1017/S0033822200057659.

Pomponi F and Moncaster A (2016) Embodied carbon mitigation and reduction in the built environment - what does the evidence say? Journal of Environmental Management 181: 687-700, https://doi.org/ 10.1016/j.jenvman.2016.08.036.

Pongiglione M and Calderini C (2014) Material savings through structural steel re-use: a case study in Genoa. Resources, Conservation and Recycling 86: 87-92, https://doi.org/10.1016/j. resconrec.2014.02.011.

Quagliarini E, Lenci S, Piattoni Q et al. (2014) Experimental analysis of Romanesque masonries made by tile and brick fragments found at the archaeological site of S. Maria in Portuno. International Journal of Architectural Heritage 8(2): 161-184, https://doi.org/10.1080/ 15583058.2012.683132.

Rangel CS, Amario M, Pepe M et al. (2017) Tension stiffening approach for interface characterization in recycled aggregate concrete. Cement and Concrete Composites 82: 176-189, https://doi.org/10.1016/j. cemconcomp.2017.06.009.

Rebrick (2013) http://ec.europa.eu/environment/eco-innovation/projects/ en/projects/rebrick (accessed 10/07/2017).

Rehman N, Lam D, Dai X and Ashour AF (2018) Testing of composite beam with demountable shear connectors. Proceedings of the Institution of Civil Engineers - Structures and Buildings 170(1): 3-16, https://doi.org/10.1680/jstbu.16.00172. 
Recovery and reuse of structural products

from end-of-life buildings

Hopkinson, Chen, Zhou, Wang and Lam
Salama W (2017) Design of concrete buildings for disassembly: an explorative review. International Journal of Sustainable Built Environment 6(2): 617-635, https://doi.org/10.1016/j.ijsbe.2017.03.005.

Sansom M and Avery N (2014) Briefing: Reuse and recycling rates of UK steel demolition arisings. Proceedings of the Institution of Civil Engineers - Engineering Sustainability 167(3): 89-94, https://doi.org/ 10.1680/ensu.13.00026.

Schebek L, Schnitzer B, Blesinger D et al. (2017) Material stocks of the non-residential building sector: the case of the Rhine-Main area. Resources, Conservation and Recycling 123: 24-36, https://doi.org/10. 1016/j.resconrec.2016.06.001

Segro (2013) Delivering: Corporate Responsibility and Sustainability Report 2013. Segro. Slough, UK. See http://www.segro.com/ /media/ Files/S/Segro/csr-report/csr-2013.pdf (accessed 09/08/2018).

Serlorenzi M, Coletti F, Traini L and Camporeale S (2016) The Domus Tiberiana Project (Rome): the supply of bricks for the Hadrianic construction works along the Nova Via. Arqueologia De La Arquitectura 13: e045, https://doi.org/10.3989/arq.arqt.2016.163 (in Italian).

Sisti R, Corradi M and Boni A (2016) An experimental study on the influence of composite materials used to reinforce masonry ring beams. Construction and Building Materials 122: 231-241, https://doi. org/10.1016/j.conbuildmat.2016.06.120.

Stephan A and Athanassiadis A (2018) Towards a more circular construction sector: estimating and spatialising current and future nonstructural material replacement flows to maintain urban building stocks. Resources, Conservation \& Recycling 129: 248-262, https:// doi.org/10.1016/j.resconrec.2017.09.022.

Tectonica-online (2018) http://www.tectonica-online.com/topics/energy/ embodied-energy-materials-enrique-azpilicueta/table/31/\#txt (accessed 07/01/2018).

Thormark C (2000) Including recycling potential in energy use into the life-cycle of buildings. Building Research \& Information 28(3): 176-183, https://doi.org/10.1080/096132100368948.

Tingley DD and Davison B (2012) Developing an LCA methodology to account for the environmental benefits of design for deconstruction. Building and Environment 57: 387-395, https://doi.org/10.1016/j. buildenv.2012.06.005.

Tingley DD, Cooper S and Cullen J (2017) Understanding and overcoming the barriers to structural steel re-use, a UK perspective. Journal of Cleaner Production 148: 642-652, https://doi.org/10.1016/j.jclepro. 2017.02 .006
UIA (Urban Innovation Actions) (2018) Identify and Test Innovative Solutions for Sustainable Urban Development. UIA, Lille, France. See http://www.uia-initiative.eu/en/uia-cities/kerkrade (accessed 23/05/ 2018).

UNEP (UN Environment Programme) (2014) Sand, Rarer Than One Thinks. UNEP, Nairobi, Kenya. See https://na.unep.net/geas/archive/ pdfs/GEAS Mar2014 Sand Mining.pdf (accessed 19/07/2018).

US EPA (US Environmental Protection Agency) (2003) Background Document for Life-cycle Greenhouse Gas Emission Factors for Clay Brick Re-use and Concrete Recycling. US EPA, Washington, DC, USA, EPA530-R-03-017.

Wang P, Li W and Kara S (2017) Cradle-to-cradle modeling of the future steel flow in China. Resources, Conservation and Recycling 117(Part A): 45-57, https://doi.org/10.1016/j.resconrec.2015.07.009.

Webster M and Costello D (2005) Designing structural systems for deconstruction: how to extend a new building's useful life and prevent it from going to waste when the end finally comes. Greenbuild Conference, Atlanta, GA, USA. See http://www.lifecyclebuilding.org/ docs/Designing $\% 20$ Structural $\% 20$ Systems $\% 20$ for $\% 20$ Deconstruction. pdf (accessed 14/08/2018).

Weil M (2003) Ressourcenschonung und Umweltentlastung bei der Betonherstellung durch Nutzung von Bau- und Abbruchabfällen. Dissertation, Fachbereich Bauingenieurwesen und Geodäsie, Technischen Universität Darmstadt, Darmstadt, Germany. (in German).

Wiedenhofer D, Steinberger JK, Eisenmenger N and Haas W (2015) Maintenance and expansion: modeling material stocks and flows for residential buildings and transportation networks in the EU25. Journal of Industrial Ecology 19(4): 538-551, https://doi.org/10.1111/jiec. 12216.

Xiao J, Ma Z and Ding T (2016) Reclamation chain of waste concrete: a case study of Shanghai. Waste Management 48: 334-343, https://doi. org/10.1016/j.wasman.2015.09.018.

Yeap KS, Yaacob NM, Rao SP and Hashim NR (2012) Incorporating waste into an experimental school prototype: lessons regarding materials reclamation opportunities. Waste Management \& Research 30(12): 1251-1260, https://doi.org/10.1177/0734242x12465459.

Yeung J, Walbridge S and Haas C (2015) The role of geometric characterization in supporting structural steel re-use decisions. Resources, Conservation and Recycling 104(Part A): 120-130, https:// doi.org/10.1016/j.resconrec.2015.08.017.

\section{How can you contribute?}

To discuss this paper, please email up to 500 words to the editor at journals@ice.org.uk. Your contribution will be forwarded to the author(s) for a reply and, if considered appropriate by the editorial board, it will be published as discussion in a future issue of the journal.

Proceedings journals rely entirely on contributions from the civil engineering profession (and allied disciplines). Information about how to submit your paper online is available at www.icevirtuallibrary.com/page/authors, where you will also find detailed author guidelines. 